\title{
The Iconometrical Perspective of the early Cōla Images
}

\author{
Subashini Venkatraman \\ Eritrea Institute of Technology \\ Dept. of Computer Engg. \\ Eritrea
}

\begin{abstract}
Iconometry is the study of an icon or image of god/goddess or human being with reference to the measurements of the parts of the icons or images. The original works dealing with sculpture are Kāśyapa Śilpam and Mānasam. Both these works deal with very branch of Silpa. The texts of Agastya, Käsyapa and Viśwakarma are followed in carving sculptures in south India. These works describe in detail, the various systems and the material to be used for carving different god/goddess icons. The point to point measurement can be taken for the whole icon from head to toe by defining different parts of the body. This paper delineates the definition of several systems described in the Śästra and the least square difference between the actual measurements of the icons and the calculated measure with respect to each system taken into consideration for the study. A random sample of the icons of the early Cóla period is collected and clusters are formed based on their classification of the tālamāna system.
\end{abstract}

\section{General Terms}

Image analysis, Information Processing

\section{Keywords}

Iconometry, Tālamāna system,.

\section{INTRODUCTION}

Iconometry is the study of an icon of god/goddess or human being with reference to the measurements of the parts of the icons. Iconometry is a science that deals with the measurements of the images that may differ from region to region and period to period in the Indian context. It helps to identify the tâlamāna system used for an image that is different from Gupta to Pandya and Cōla. The details regarding measurements of the anga "parts" (e.g. the length of nose, the breadth and width of eyes and so on) are laid down in the silpaśāstra and àgama. The original works dealing with sculpture are Käśsapa Silpam[1] and Mānasam. Both these works deal with very branch of Silpa. Especially in South India the works of Agastya, Käśyapa and Viśwakarma are followed in carving sculpture. In Agastya Sakalädhikāra[2] eleven ways are specified by which the height of an image can be determined. Sri. GanAPATHI STHAPATHI [3] in his book "Sirpa Chennool", has written the significance and elegance of making the icons using different materials and methods. This serves as the proper text book and guide for the artisans and students.

\section{RELATED WORKS}

A study of iconometric measurements will generally prove useful in dating sculptures, in restoration work, in checking whether any of the known canons of iconometry were followed by the sculptors, and for hypothesizing about the number of sculptors who executed the work, as GURALNICK.E[4] did in her pioneering application of statistical and computer methods to the study of Greek Iconometry. JOHN F. MOSTELLER [5] has surveyed the contributions made in Indian Iconometry during a period of 1900-1945. In an earlier study of iconometry, by SiRomoney.G, [6] et al., point-to-point distances were measured and an analysis was done using multivariate analysis of the data for the carvings in the Kailasanatha Temple. Early Pandya Iconometry has been studied by GOPALAKRISHNAN.S, [7] using hierarchical clustering and correlation analysis. In another work Siromoney.G, [8] investigated the tâlamāna system on Pallava Sculptures at Mamallapuram. JoHN F. MostelLER [9] has published a report on the development and application of a quantitative approach for the study of Indian art utilizing imaging technology. A project on Iconometry and Icon Makers has been executed by THANGAVELU. S [10] has detailed about the methods of carving the sculptures in his project report. C.N. RAVi Kumar and MANimala. S [11] proposed a method constructing human middle finger from its fractional part using tālamāna system.

\section{TĀLAMĀNA SYSTEM}

Canons of iconometry follow the ancient "Tãlamāna" system in which the basic units are the ańgula and the tāla, and the latter stands for the length of the palm. The angula is either a fixed length or a proportion. A span can be defined in many ways namely Mulaberanglam ${ }^{1}$, Mananglam ${ }^{2}$ or Matharangulam ${ }^{3}$. A tâla or span is defined to be 12 ańgulas in the texts and an ańgula is approximately equivalent to $3 / 4^{\text {th }}$ of present day inch in use. Ańgula may be defined as proportionate measure and fixed measure. The measurement of angula is divided into 8 yavas. The measurement of the features of an image is of four types, namely (1)length (2) breadth (3) width (4) dealing with interspaces. According to the Indian iconometry system, a sculpture could be made according to one of the ten main types of proportions. Each type is further sub-divided into three subtypes. For each sculpture of a god/goddess' a standard height is defined and based on the standard height the measurement of other parts of the body are described. The heights are standard with due reference to each god/goddess and classified into ten ${ }^{4}$ main measurement of heights from 1 to 10 tālas. Out of these ten measures if 4 ańgulas are added from Tritāla to Dasatāla

\footnotetext{
${ }^{1}$ The height of the Mulasathanam should be considered to find the measure of an ańgula.

${ }^{2}$ Yava is a special variety of wheat grain/ $1 / 8^{\text {th }}$ of an angula is yava. Sali is a paddy grain. The size of these grains should be considered to determine the ańgula measure.

${ }^{3}$ The length of the palm of the Yajamana or the length or width of the middle part of the middle finger of the yajamana can be used for determining the angula.

${ }^{4}$ Eka, Dvi, Tri, Cadur, Panca, Shad, Sapta, Ashta, Nava, Dasa.
} 
then it is called Uttama; and if 4 ańgulas are subtracted then it is called Adhama, otherwise it is known as Madhyama. The classification of a tālamāna system for carving different god/goddess is specified in Kāśyapa Śāstram. For the study, the last three systems are taken into consideration with their subdivisions.

\subsection{Types of Tālamāna System}

The classification of images into different Tãlamana system from 1 to 10 tâla is detailed below. (See Table 1).

Table 1 Tālamāna System

\begin{tabular}{|c|c|c|}
\hline No & Tālamāna & Images \\
\hline 1. & Uttamadasa & Brahma, Visnu, Maheswara \\
\hline 2. & Madhyamadasa & $\begin{array}{l}\text { Uma, Saraswati,Usha devi, Bhudevi, } \\
\text { Durga, Lakshmi, } \\
\text { Sapta Mata, Jyeshta devi }\end{array}$ \\
\hline 3. & Adhamadasa & $\begin{array}{l}\text { Candran, Suryan, Asvini Deva's, } \\
\text { Maharisi's, } \\
\text { Navagraha, Ayyanar, Shanmugan, } \\
\text { Candikeswarar, } \\
\text { Kshetrabalakas (Bhairava) }\end{array}$ \\
\hline 4. & Uttamanava & $\begin{array}{l}\text { Ashta Murti's, Vidhyadhiba's, } \\
\text { Lokabala's, other Deva's }\end{array}$ \\
\hline 5. & Madhyamanava & $\begin{array}{l}\text { Yaksha's, Apsara's, Asthra murty, } \\
\text { mruthgana's }\end{array}$ \\
\hline 6. & $\begin{array}{l}\text { Adhamanava } \\
\text { (Kanishta) }\end{array}$ & Asura, siddha,Gandharva,Pithrukal \\
\hline 7. & Ashta & Sathiyar (Human Being) \\
\hline 8. & Sapta & Pisasanga \\
\hline 9. & Shad & Kupjakar \\
\hline 10. & Panca & Vigneswara \\
\hline 11. & $\begin{array}{l}\text { Madhyama } \\
\text { Panca }\end{array}$ & Bhuda ganas \\
\hline 12. & Chadur & Balabera \\
\hline 13. & Tri & Kinnaras \\
\hline 14. & Dhvi & Kimpurusha \\
\hline 15. & $E k a$ & Kurmam \\
\hline
\end{tabular}

\section{DATABASE DESCRIPTION}

The sculptures of the early Cōla period are taken as the database for the study. The icons under study are all in the standing position. A random sample of the early Côla icons is collected from the Tanjore Art Gallery, Government Museum, Chennai and also from the temples in and around Tanjore. The height of the icons and the linear measure of the parts are obtained in centimeter. Table 2 represents the variable description for the parts of the icon. There are 13 independent variables representing the parts of the icons and 1 dependent variable representing the height of the icon (sum of the measurements of the parts of the icon). The measurements are point to point and linear (length) in nature and their volumetric measures are not taken. As the structure of the parts is not regular in shape (cannot be mapped to any geometrical shape) there is no appropriate measuring tool to measure them exactly. The parts are mostly measured using vernier caliper or using the traditional system of threads.

Table 2 Variable Description

\begin{tabular}{|c|c|c|}
\hline No & $\begin{array}{l}\text { Variable } \\
\text { Name }\end{array}$ & Description \\
\hline 1. & TUFT & The Length of the Tuft \\
\hline 2. & FHLN & $\begin{array}{l}\text { Hairline on forehead to } \\
\text { root of the eyebrows }\end{array}$ \\
\hline 3. & EBEL & $\begin{array}{l}\text { Root of the eyebrows to } \\
\text { eye lashes }\end{array}$ \\
\hline 4. & NOLN & Nose length \\
\hline 5. & NCLN & $\begin{array}{l}\text { From end of nose to } \\
\text { lower part of the chin }\end{array}$ \\
\hline 6. & NELN & $\begin{array}{l}\text { From the end of the chin to } \\
\text { bottom of the Adam's apple }\end{array}$ \\
\hline 7. & NCHN & $\begin{array}{l}\text { From the bottom of Adam's } \\
\text { apple to chest little } \\
\text { below of nipples }\end{array}$ \\
\hline 8. & CHNN & From chest to centre of navel \\
\hline 9. & NGLN & Centre of navel to root of penis \\
\hline 10 . & THLN & $\begin{array}{l}\text { From root of penis to top of } \\
\text { knee }\end{array}$ \\
\hline 11. & KNLN & Top to bottom of knee \\
\hline 12. & CALN & Bottom of knee to top of ankle \\
\hline 13. & FOLN & Top of ankle to root of foot \\
\hline 14. & TOHT & The total height from tuft to foot \\
\hline
\end{tabular}

Apart from the above described measurements the width of the shoulder, width of hip and the pointing finger length are also measured for investigation and to check whether any interesting results could be obtained during the analysis.

Table 3 System Description

\begin{tabular}{|l|l|c|}
\hline S.No & Tālamāna System & $\begin{array}{c}\text { System } \\
\text { Number }\end{array}$ \\
\hline 1 & UttamadasaTāla & $\mathbf{1}$ \\
\hline 2 & MadhyamadasaTāla & $\mathbf{2}$ \\
\hline 3 & AdhamadasaTāla & $\mathbf{3}$ \\
\hline 4 & UttamanavaTāla & $\mathbf{4}$ \\
\hline 5 & MadhyamanavaTāla & $\mathbf{5}$ \\
\hline 6 & AdhamanavaTāla & $\mathbf{6}$ \\
\hline 7 & AshtaTāla & $\mathbf{7}$ \\
\hline
\end{tabular}




\section{ALGORITHM}

\subsection{Least Square Method}

Let $n$ be the number of variables defined which represent different measures of the parts of the image and $m$ be the number of systems under study. Let $x_{i} i=1,2, \ldots, n$ be the actual measurements taken for the sample icons. Let $y_{i j}$ be the corresponding calculated measurements for the $i^{\text {th }}$ icon under the $j^{\text {th }}$ system where $i=1,2, \ldots, n$ and $j=1,2, \ldots, m$. Let $d_{j}$ be the squared difference calculated with respect to each measurement of the parts of the body of the sample image for the $j^{\text {th }}$ system. Let there be $m$ clusters

$d_{j}=\sum_{i=1}^{n}\left(y_{i j}-x_{i}\right)^{2} ; i=1,2, \ldots, n ; j=1,2, \ldots m$

$d=\min \left(d_{j}\right) ; j=1,2, \ldots, m$

Step 1

Let $x_{i}$ be the actual measurements taken for each of the sample images for all the variables defined in Table.

Step 2

Let $y_{i j}$ be the $i^{\text {th }}$ variable measurement calculated based on the $j^{\text {th }}$ system proportions. For every sample there will be $m$ set of system based measurements.

Step 3

For each sample, using the formula (4.1) the squared difference is calculated between the actual measurements and the calculated system measurements $d_{j}$ for $j=1,2, \ldots, m$.

Step 4

The minimum of $d_{j}$ is obtained using the formula (4.2) for $j=$ $1,2, \ldots, m$.

Step 5

The sample image is grouped into one of the $m$ clusters depending on the value of $d$.

Step 6

The algorithm forms $m$ clusters of images. No two clusters will have the same image. The total number of images in all the clusters will be equivalent to the number of sample images considered for clustering.

\subsection{Implementation of The Algorithm}

The calculation for two of the samples collected is shown in Table 4 (Sample No: 31 Mahaviśnu) and in Table 5 (Sample No:16 Siva. Column M shows the actual measurement taken from the icon and column $\mathrm{C}$ shows the calculated measurement. The measurements of different parts of the icon specified in Table 2 under the tâlamāna systems described in Table 3 are shown.

In the present study, $m$ is seven and the $n$ value is thirteen. The result of the algorithm will yield seven mutually exclusive clusters. In our calculation the proportionate measure of ańgula is used as described in the sastra instead of the fixed measure. The angula measure is calculated by dividing the total height of the icon with the number of parts defined under each system.
For example, under Uttamadasatāla there are 124 parts. Hence the total height of the Sample No.31 Mahaviśnu $164 \mathrm{~cm}$ is divided by 124 to get the proportionate angula measure. The calculation based on the proposed algorithm is shown only for two images for reference.

From this analysis, the calculated proportional length of the parts described in Table 2 differs from the prescribed proportion. But when the overall proportion of the face, upper part, lower part and the feet of the icon are considered the calculated proportional length is equal to the actual measurement allowing a 2 to 5 percent of permissible error. For example the face length is divided in to 3 parts. The calculated length of the individual parts is not equal to the actual measurement. Instead if the face length is taken as a whole, then the In the same manner, if the length of the leg is taken as whole the calculated and actual measurements are equal. Hence the study gives the inference that there must be some deviation done by the artisans from the original proportions given in the Śāstra to the present day proportions from time to time. The future study aims to find out the reasoning behind this variation.

M-Actual Measurement C- Calculated measurement Table 4 Calculation for Sample No: 31 Mahaviśnu

\begin{tabular}{|c|c|c|c|c|c|c|c|c|c|c|c|c|c|}
\hline & $\cup$ & $\Sigma$ & $\cup$ & $\Sigma$ & $u$ & $\Sigma$ & $u$ & $\Sigma$ & $u$ & $\Sigma$ & $u$ & $\Sigma$ & U \\
\hline$\vec{n}$ & -1 & & $N$ & & $m$ & & $\nabla$ & & $n$ & & ( ) & & $N$ \\
\hline 产 & $\begin{array}{l}8 \\
\dot{+} \\
0 \\
-1\end{array}$ & 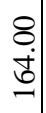 & 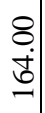 & $\begin{array}{l}8 \\
\text { ț } \\
\underline{0}\end{array}$ & $\begin{array}{l}8 \\
\dot{+} \\
\underline{-}\end{array}$ & $\begin{array}{l}8 \\
\text { d̦ } \\
\underline{0}\end{array}$ & 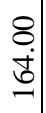 & $\begin{array}{l}8 \\
\dot{0} \\
\dot{0} \\
-\end{array}$ & $\begin{array}{l}8 \\
\dot{0} \\
\dot{0} \\
-\end{array}$ & $\begin{array}{l}8 \\
\dot{0} \\
\dot{0}\end{array}$ & $\begin{array}{l}8 \\
\dot{0} \\
\dot{0} \\
-\end{array}$ & 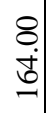 & $\begin{array}{l}8 \\
8 \\
\dot{0}\end{array}$ \\
\hline 导 & 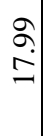 & 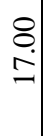 & 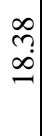 & 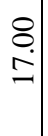 & 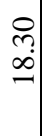 & $\begin{array}{c}8 \\
\\
-\end{array}$ & \begin{tabular}{l}
\multirow{2}{}{} \\
$\infty$ \\
-
\end{tabular} & $\begin{array}{l}8 \\
\vdots \\
-\end{array}$ & $\begin{array}{l}\stackrel{2}{ } \\
\infty \\
-1\end{array}$ & $\begin{array}{l}8 \\
\vdots \\
-\end{array}$ & $\begin{array}{l}0 \\
\\
\infty \\
-1\end{array}$ & $\begin{array}{l}8 \\
\vdots \\
-\end{array}$ & $\begin{array}{c}\hat{\imath} \\
\infty\end{array}$ \\
\hline 焉 & 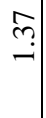 & & $\stackrel{ت}{ت}$ & & $\begin{array}{l}0 \\
\stackrel{0}{+} \\
-\end{array}$ & & กี & & ñ & & $\stackrel{\overbrace{}}{-}$ & & 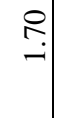 \\
\hline 国 & $\begin{array}{l}8 \\
\dot{6}\end{array}$ & 8 & $\stackrel{2}{6}$ & $\begin{array}{l}8 \\
\dot{n}\end{array}$ & ஜ̂. & $\begin{array}{l}8 \\
\dot{n}\end{array}$ & bo & $\begin{array}{l}8 \\
\dot{n}\end{array}$ & $\stackrel{0}{\circ}$ & $\begin{array}{l}8 \\
\dot{n}\end{array}$ & $\frac{7}{6}$ & $\begin{array}{l}8 \\
\dot{n}\end{array}$ & $\begin{array}{l}8 \\
0\end{array}$ \\
\hline $\begin{array}{l}\text { Z } \\
\text { ○) } \\
\text { Z }\end{array}$ & $\begin{array}{l}8 \\
0 \\
0\end{array}$ & $\begin{array}{l}0 \\
\\
\text { a. }\end{array}$ & 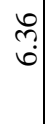 & 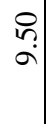 & $\begin{array}{l}0 \\
\infty \\
\dot{n}\end{array}$ & 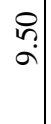 & 匇 & 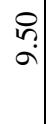 & $\stackrel{0}{6}$ & $\begin{array}{l}0 \\
\\
\text { n. }\end{array}$ & $\frac{7}{6}$ & $\begin{array}{l}0 \\
\\
\text { n. }\end{array}$ & \& \\
\hline $\begin{array}{l}Z \\
Z \\
Z\end{array}$ & $\begin{array}{l}8 \\
\vdots \\
0\end{array}$ & $\begin{array}{l}\stackrel{0}{n} \\
i n\end{array}$ & ?̊. & $\begin{array}{l}8 \\
n \\
n\end{array}$ & $\begin{array}{l}0 \\
\infty \\
i\end{array}$ & 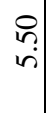 & $\begin{array}{l}5 \\
0 \\
0\end{array}$ & $\begin{array}{l}0 \\
n \\
n\end{array}$ & $\begin{array}{l}0 \\
6 \\
0\end{array}$ & $\begin{array}{l}0 \\
n \\
n\end{array}$ & $\frac{7}{6}$ & $\begin{array}{l}\text { in } \\
\text { ñ }\end{array}$ & \& \\
\hline 写 & $\begin{array}{l}8 \\
6 \\
0\end{array}$ & \begin{tabular}{l}
$\stackrel{0}{n}$ \\
\hdashline \\
\hdashline
\end{tabular} & $\begin{array}{l}0 \\
0 \\
\dot{n}\end{array}$ & $\begin{array}{c}0 \\
? \\
0\end{array}$ & $\begin{array}{l}0 \\
\infty \\
\dot{r}\end{array}$ & $\begin{array}{l}\stackrel{0}{n} \\
\stackrel{?}{0}\end{array}$ & $\begin{array}{l}\hat{0} \\
0\end{array}$ & $\begin{array}{c}0 \\
\vdots \\
0\end{array}$ & 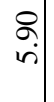 & $\begin{array}{c}0 \\
\vdots \\
0\end{array}$ & ñ? & $\begin{array}{l}0 \\
? \\
0\end{array}$ & $\curvearrowleft$ \\
\hline $\begin{array}{l}\text { Z } \\
\text { 至 } \\
\text { Z }\end{array}$ & $\begin{array}{l} \pm \\
m \\
\infty\end{array}$ & $\begin{array}{l}8 \\
\infty \\
\infty\end{array}$ & $\begin{array}{l}\infty \\
\vdots \\
\infty \\
-1\end{array}$ & $\begin{array}{l}8 \\
\infty \\
\infty\end{array}$ & 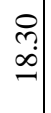 & $\begin{array}{l}8 \\
\infty \\
\infty\end{array}$ & 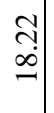 & $\begin{array}{c}8 \\
\infty \\
\infty\end{array}$ & $\begin{array}{l}\grave{2} \\
\infty\end{array}$ & $\begin{array}{c}8 \\
0 \\
\infty\end{array}$ & 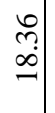 & $\begin{array}{c}8 \\
\infty \\
\infty\end{array}$ & N \\
\hline
\end{tabular}




\begin{tabular}{|c|c|c|c|c|c|c|c|c|c|c|c|c|c|}
\hline 畜 & $\begin{array}{c}\stackrel{+}{m} \\
\dot{\infty}\end{array}$ & $\begin{array}{l}8 \\
\dot{\lambda}\end{array}$ & $\begin{array}{l}\infty \\
\stackrel{\infty}{\infty} \\
\infty \\
\infty\end{array}$ & $\begin{array}{l}8 \\
\stackrel{\lambda}{\sim}\end{array}$ & 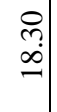 & $\begin{array}{l}8 \\
\stackrel{\Delta}{\sim}\end{array}$ & $\begin{array}{c}\tilde{\Xi} \\
\infty \\
\infty\end{array}$ & $\underset{\mathrm{i}}{\mathrm{i}}$ & 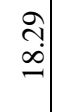 & $\begin{array}{l}8 \\
\dot{\lambda} \\
-1\end{array}$ & 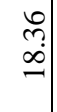 & $\begin{array}{l}8 \\
\dot{\lambda} \\
-1\end{array}$ & $\begin{array}{l}\hat{T} \\
\infty \\
-\infty\end{array}$ \\
\hline Z & 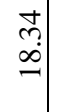 & 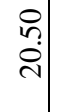 & $\begin{array}{c}\infty \\
\stackrel{\infty}{0} \\
\infty\end{array}$ & $\begin{array}{l}0 \\
\stackrel{n}{n} \\
\grave{n}\end{array}$ & 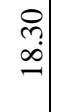 & $\begin{array}{l}0 \\
\stackrel{n}{2} \\
\grave{n}\end{array}$ & $\begin{array}{c}\tilde{N} \\
\infty \\
\infty\end{array}$ & $\begin{array}{l}\text { กี } \\
\text { กิ }\end{array}$ & 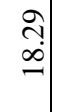 & $\begin{array}{l}0 \\
\text { in. } \\
\vdots\end{array}$ & $\begin{array}{l}0 \\
\tilde{n} \\
\infty \\
\infty\end{array}$ & $\begin{array}{l}0 \\
\text { ñ. } \\
\vdots\end{array}$ & $\begin{array}{l}\hat{ָ} \\
\infty \\
\infty\end{array}$ \\
\hline 畕 & 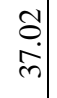 & 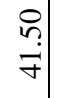 & $\begin{array}{l}0 \\
\stackrel{0}{6} \\
\stackrel{0}{0}\end{array}$ & 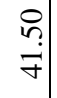 & $\begin{array}{l}\vec{b} \\
\dot{b} \\
\stackrel{n}{0}\end{array}$ & $\begin{array}{l}\stackrel{0}{n} \\
\dot{q}\end{array}$ & 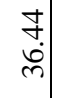 & $\frac{n}{7}$ & 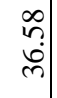 & 官 & 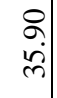 & 官 & 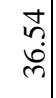 \\
\hline$z^{z}$ & $\begin{array}{c}\infty \\
\dot{\sim} \\
\dot{n}\end{array}$ & $\stackrel{?}{r}$ & $\begin{array}{l}: \\
\dot{r}\end{array}$ & $\stackrel{?}{r}$ & $\begin{array}{l}0 \\
\infty \\
\dot{r}\end{array}$ & $\stackrel{?}{r}$ & 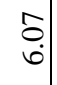 & $\stackrel{?}{r}$ & $\begin{array}{l}\curvearrowright \\
\grave{n}\end{array}$ & $\stackrel{?}{r}$ & ?ึ. & $\begin{array}{c}\stackrel{?}{?} \\
\sim\end{array}$ & $\begin{array}{l}\Re \\
\tilde{n}\end{array}$ \\
\hline 壳 & 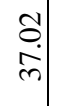 & 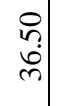 & $\begin{array}{l}\stackrel{0}{0} \\
\dot{\rho}\end{array}$ & 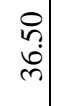 & $\begin{array}{l}\vec{b} \\
\dot{d}\end{array}$ & 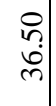 & $\begin{array}{l}7 \\
\dot{0} \\
\dot{n}\end{array}$ & $\begin{array}{l}\text { ñ } \\
\text { in }\end{array}$ & 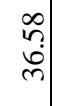 & 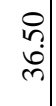 & $\begin{array}{l}\stackrel{8}{0} \\
\dot{n}\end{array}$ & 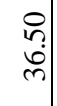 & 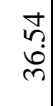 \\
\hline Z & $\begin{array}{c}\stackrel{\infty}{+} \\
\dot{r}\end{array}$ & $\begin{array}{l}n \\
\text { nุ. }\end{array}$ & $\begin{array}{c}8 \\
\stackrel{1}{1}\end{array}$ & \begin{tabular}{c}
$\stackrel{0}{0}$ \\
\hdashline
\end{tabular} & $\begin{array}{l}0 \\
\infty \\
\dot{\sim} \\
\dot{n}\end{array}$ & 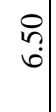 & 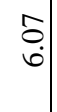 & ?ึ & $\begin{array}{l}\stackrel{2}{2} \\
\dot{n}\end{array}$ & 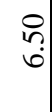 & $\begin{array}{l}\vec{r} \\
\dot{n}\end{array}$ & 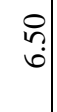 & $\begin{array}{l}n \\
\check{n}\end{array}$ \\
\hline
\end{tabular}

Table 5 Calculation of Sample No:16 Siva

\begin{tabular}{|c|c|c|c|c|c|c|c|c|c|c|c|c|c|}
\hline & $u$ & $\Sigma$ & $u$ & $\Sigma$ & U & $\Sigma$ & $u$ & $\Sigma$ & $u$ & $\Sigma$ & U & $\Sigma$ & $U$ \\
\hline 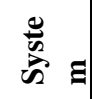 & - & & $N$ & & $m$ & & $\nabla$ & & is & & 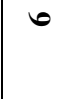 & & $N$ \\
\hline$\underset{\overline{0}}{\underline{0}}$ & $\begin{array}{l}n \\
\stackrel{n}{=} \\
=\end{array}$ & $\begin{array}{l}n \\
= \\
=\end{array}$ & $\begin{array}{l}n \\
= \\
=\end{array}$ & $\begin{array}{l}n \\
= \\
=\end{array}$ & \begin{tabular}{l}
$n$ \\
\hdashline \\
$=$
\end{tabular} & $\begin{array}{l}n \\
= \\
=\end{array}$ & $\begin{array}{l}\mathfrak{n} \\
\ddots \\
=\end{array}$ & $\stackrel{n}{0}$ & $\stackrel{n}{0}$ & $\stackrel{n}{\stackrel{n}{0}}$ & $\stackrel{n}{0}$ & $\stackrel{n}{6}$ & $\stackrel{n}{=}$ \\
\hline 志 & $\begin{array}{l}\infty \\
\stackrel{0}{\mathrm{i}}\end{array}$ & $\stackrel{n}{n}$ & $\begin{array}{l}\stackrel{0}{0} \\
\stackrel{2}{2}\end{array}$ & $\stackrel{n}{2}$ & $\cong$ & $\stackrel{n}{\check{\vartheta}}$ & 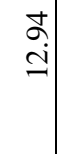 & $\stackrel{\sim}{\dddot{2}}$ & $\stackrel{2}{\jmath}$ & $\stackrel{n}{2}$ & $\underset{\stackrel{d}{0}}{\stackrel{\Delta}{2}}$ & $\stackrel{\sim}{2}$ & $\stackrel{\infty}{\text { తి }}$ \\
\hline 突 & $\hat{o}$ & & - & & 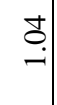 & & $\stackrel{\infty}{\stackrel{\sim}{\circ}}$ & & 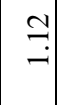 & & $\stackrel{?}{=}$ & & 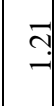 \\
\hline 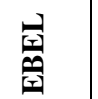 & $\begin{array}{l}\stackrel{?}{+} \\
+\end{array}$ & $m$ & $\stackrel{f}{+}$ & $\tilde{n}$ & $\begin{array}{l}\infty \\
\stackrel{\leftrightarrow}{+} \\
\stackrel{0}{0}\end{array}$ & $\stackrel{n}{n}$ & $\vec{m}$ & $n$ & $\stackrel{m}{+}$ & $\stackrel{n}{n}$ & $\stackrel{m}{\dot{r}}$ & $\stackrel{n}{m}$ & $\stackrel{\oplus}{\sim}$ \\
\hline $\begin{array}{l}Z \\
\bar{O} \\
Z\end{array}$ & $\begin{array}{l}\stackrel{?}{1} \\
\stackrel{+}{+}\end{array}$ & $r$ & $\stackrel{\widetilde{v}}{\tilde{+}}$ & $r$ & $\begin{array}{l}\stackrel{0}{\circ} \\
\dot{+}\end{array}$ & $r$ & $\vec{m}$ & $r$ & $\stackrel{?}{\rightarrow}$ & $r$ & $\stackrel{\Re}{\stackrel{r}{r}}$ & $r$ & $\stackrel{m}{\sim}$ \\
\hline$\underset{Z}{Z}$ & $\begin{array}{l}\stackrel{?}{+} \\
+\end{array}$ & $n$ & $\stackrel{\hat{n}}{\dot{m}}$ & in & $\stackrel{\bullet}{\stackrel{0}{+}}$ & $n$ & $\bar{m}$ & in & $\stackrel{m}{\rightarrow}$ & in & $\stackrel{\dddot{m}}{f}$ & $n$ & $\stackrel{m}{\vec{t}}$ \\
\hline 六 & $\begin{array}{l}\vec{\imath} \\
\stackrel{+}{+}\end{array}$ & $a$ & $\begin{array}{l}\Omega \\
\dot{+}\end{array}$ & $a$ & $\begin{array}{l}\stackrel{0}{\circ} \\
\dot{+}\end{array}$ & $a$ & $\vec{m}$ & $a$ & $\stackrel{\vartheta}{\vec{f}}$ & $a$ & $\begin{array}{l}\mathbb{f} \\
\stackrel{+}{*}\end{array}$ & $a$ & $\stackrel{\overbrace{}}{f}$ \\
\hline
\end{tabular}

\begin{tabular}{|c|c|c|c|c|c|c|c|c|c|c|c|c|c|}
\hline 㝟 & 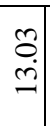 & 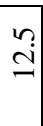 & 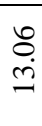 & $\stackrel{n}{\simeq}$ & 9 & $\stackrel{\sim}{\simeq}$ & $\begin{array}{l}\vec{J} \\
\mathrm{~d}\end{array}$ & $\begin{array}{l}\tilde{a} \\
\simeq\end{array}$ & $\begin{array}{l}\stackrel{a}{\mathrm{i}} \\
\mathbf{n}\end{array}$ & $\begin{array}{l}n \\
\end{array}$ & $\begin{array}{c} \pm \\
\dot{d} \\
-\end{array}$ & $\stackrel{n}{\mathrm{i}}$ & a \\
\hline 忘 & 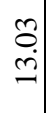 & $\stackrel{n}{ \pm}$ & 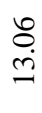 & $\stackrel{n}{ \pm}$ & $\approx$ & $\stackrel{n}{ \pm}$ & $\begin{array}{l}\dot{\sigma} \\
\mathrm{d}\end{array}$ & $\begin{array}{l}n \\
\pm \\
\pm\end{array}$ & $\begin{array}{l}\stackrel{2}{\mathrm{j}} \\
=\end{array}$ & $\stackrel{n}{ \pm}$ & $\begin{array}{c}t \\
0 \\
\end{array}$ & $\stackrel{n}{ \pm}$ & a \\
\hline $\begin{array}{l}\text { Zu } \\
\text { Z }\end{array}$ & 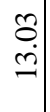 & $\stackrel{n}{\dddot{m}}$ & 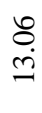 & $\stackrel{\sim}{\sim}$ & $\approx$ & 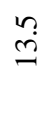 & 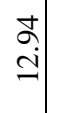 & $\begin{array}{l}n \\
n\end{array}$ & $\begin{array}{l}\stackrel{\partial}{\mathrm{d}} \\
\mathbf{y}\end{array}$ & $\begin{array}{l}n \\
\end{array}$ & $\begin{array}{c}t \\
\dot{g} \\
-\end{array}$ & $\stackrel{n}{2}$ & a \\
\hline 盇 & 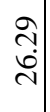 & ते & $=$ & ते & ㄴ) & ন & $\begin{array}{l}\text { के } \\
\dot{c}\end{array}$ & ते & $\begin{array}{l}\infty \\
\stackrel{d}{d} \\
\dot{c}\end{array}$ & ते & $\begin{array}{l}n \\
\mathfrak{c}\end{array}$ & ते & 월 \\
\hline 亘 & ले. & $\begin{array}{l}n \\
\infty \\
\infty\end{array}$ & $\underset{\sim}{\tilde{f}}$ & $\stackrel{n}{\infty}$ & $\stackrel{\circ}{\underset{\sim}{*}}$ & $\stackrel{\infty}{\infty}$ & $\vec{m}$ & $\begin{array}{l}n \\
\infty\end{array}$ & $\stackrel{\stackrel{9}{+}}{\dot{r}}$ & $\begin{array}{l}n \\
\infty\end{array}$ & $\begin{array}{l}\vec{t} \\
\dot{f}\end{array}$ & $\begin{array}{l}n \\
\infty \\
\infty\end{array}$ & $\cong$ \\
\hline 能 & 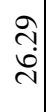 & $\vec{\sim}$ & 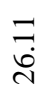 & $\bar{\sim}$ & ¿ & $\bar{\sim}$ & $\begin{array}{l}\text { के } \\
\text { cे }\end{array}$ & $\vec{\sim}$ & \begin{tabular}{l}
$\infty$ \\
\multirow{\lambda}{c}{} \\
\end{tabular} & $\vec{\sim}$ & $\begin{array}{l}n \\
\tilde{3}\end{array}$ & $\vec{\sim}$ & ปे \\
\hline 茯 & ले. & $r$ & $\underset{f}{\stackrel{f}{f}}$ & $r$ & 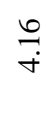 & $r$ & $\vec{m}$ & $r$ & $\stackrel{\vec{f}}{\stackrel{\partial}{+}}$ & $r$ & $\begin{array}{l}\stackrel{8}{ } \\
\dot{+}\end{array}$ & $r$ & 글 \\
\hline
\end{tabular}

\section{CONCLUSION}

In the above study, we conclude that the iconometry is very helpful in investigating the tâlamāna system which used to carve a particular icon, of the period and the place of its origin using the Least Square Difference Method. The Least Square Difference Method sounds to be promising and easy to calculate as it does not include complicated calculations. Further, any icon from Gupta, Pallava, Cōla may be classified to one of the tālamāna systems, which results in the application of data mining of the image database. Thus, the clusters formed will be useful in image retrieval using iconometry particularly for the digital images of the sculptures. As iconometry is proved to be a powerful tool in investigating the icons using their measurements, restoring the damaged icons into their original form would be easy, which depicts the significance of our rich culture.

\section{ACKNOWLEDGEMENTS}

I would like to express my gratitude to Prof. RaJU KaLIDOs (Retd.) Tamil University, Thanjavur., for his expert guidance in measuring of the icons. I am thankful to Thiru. R. BALASUBRAMANIAN, Curator, Archaeology sections of the government Museum, Chennai., for providing me special permission for data collection. 


\section{REFERENCES}

[1] Kāśyapa Śilpa Śāstram with Tamil Translation by K.S. Subramanya Sastry 1960, Tanjore Saraswati Mahal Series No:89

[2] Agastya Sakalādhikāra with Tamil Translation by K.Vasudeva Sastri 1996, Tanjore Saraswati Mahal Series No:92

[3] Ganapathi Sthapathi. V and S. Ganesan 1978. "Sirpa Chennool", Directorate of Technical Education, Tamil Nadu.

[4] Guralnick, E. (1976). "The proportions of some archaic Greek sculptured figures: a computer analysis", Computers and the Humanities, 10, 153-169.

[5] Mosteller .F. John 1988. "The Study of Indian Iconometry in Historical Perspective", Journal of the American Oriental Society, Vol. 108, No. 1 (Jan. - Mar., 1988), pp. 99-110.

[6] Siromoney, G., M.Bagavandas and S.Govindaraju, (1980) An application of component analysis to the study of South Indian sculptures, Computers and the Humanities, 14: $29-37$
[7] Gopalakrishnan S. Early Pān-yan Iconometry Sharada Publishing House, 2005.

[8] Siromoney. G 1978. "Iconometry of Pallava Sculptures, The Sunday Standard.

[9] Mosteller .F. John 1987. "A New approach for the study of Indian Art", Journal of the American Oriental Society, Vol. 107, No. 1(Jan. - Mar., 1987), pp. 55-69.

[10] Thangavelu .S (2001-2002). "Iconometry and Icon Makers", A Project Report. Nehru Trust for Indian Collections, New Delhi.

[11] Ravi Kumar C.N. and S. Manimala 2011. “A Novel Method of Constructing Human Middle Finger from its Fractional Part”, International Journal of Computer Applications, Vol. 15, No.1, (Feb., 2011). 